\title{
Prohexadione calcium on the growth and quality of eggplant seedlings
}

\author{
Nusret Ozbay(1) and Nazan Ergun(1) \\ (1)Bingol University, Faculty of Agriculture, Department of Horticulture, 12000, Bingol, Turkey. E-mail: oznusret@yahoo.com, \\ nazan.turkmen@yahoo.com
}

\begin{abstract}
The objective of this work was to evaluate the effects of prohexadione calcium concentrations on the growth and quality of eggplant (Solanum melongena) seedlings. The effects of prohexadione calcium concentrations of $0,50,100$, or $150 \mathrm{mg} \mathrm{L}^{-1}$ on seedling growth parameters were evaluated in a greenhouse experiment. After the greenhouse experiment, the seedlings were transplanted to the field. During the field experiment, the number of days to flowering, plant height, number of fruits per plant, average fruit weight and yield were evaluated. Both experiments were carried out in a completely randomized design with four replicates. All prohexadione calcium concentrations significantly reduced shoot height and internode length, when compared to the control. The concentrations of 50,100, and $150 \mathrm{mg} \mathrm{L}^{-1}$ prohexadione calcium reduced shoot height by 27,32 , and $38 \%$, respectively. Prohexadione calcium treatments (except the one with $50 \mathrm{mg}$ $\mathrm{L}^{-1}$ ) enhanced relative chlorophyll content of leaves in comparison to the control. There were no delays in flowering and no significant differences in number of fruits per plant among treatments with prohexadione calcium. The concentrations of 100 and $150 \mathrm{mg} \mathrm{L}^{-1}$ prohexadione calcium significantly reduced yield per plant and total fruit yield, whereas the concentration of $50 \mathrm{mg} \mathrm{L}^{-1}$ did not cause any change in yield compared to the control. The lowest prohexadione calcium concentration can be used to control excessive elongation of eggplant seedlings without yield loss.
\end{abstract}

Index terms: Solanum melongena, growth retardant, seedling height control.

\section{Prohexadiona de cálcio sobre o crescimento e a qualidade de mudas de berinjela}

\begin{abstract}
Resumo - O objetivo deste trabalho foi avaliar os efeitos da aplicação de prohexadiona de cálcio no crescimento e na qualidade de mudas de berinjela (Solanum melongena). Os efeitos das concentrações de 0, 50,100 ou $150 \mathrm{mg} \mathrm{L}^{-1}$ de prohexadiona de cálcio nos parâmetros de crescimento de mudas foram avaliados em experimento em casa de vegetação. Após a avaliação em casa de vegetação, as plântulas foram transplantadas para o campo. No experimento em campo, foram avaliados número de dias para o florescimento, altura de plantas, número de frutos por planta, peso médio e produtividade dos frutos. Ambos os experimentos foram realizados em delineamento inteiramente casualizado, com quatro repetições. Todas as concentrações de prohexadiona de cálcio reduziram significativamente a altura da parte aérea e o comprimento dos entrenós, em comparação ao controle. As concentrações de 50,100 e $150 \mathrm{mg} \mathrm{L}^{-1}$ de prohexadiona de cálcio reduziram a altura da parte aérea em 27, 32 e $38 \%$, respectivamente. Os tratamentos com prohexadiona de cálcio (exceto o de $50 \mathrm{mg} \mathrm{L}^{-1}$ ) aumentaram o teor de clorofila na folha, em relação ao controle. Não foram observados atrasos na floração nem diferenças significativas no número de frutos por planta entre os tratamentos com prohexadiona de cálcio. As concentrações de 100 e $150 \mathrm{mg} \mathrm{L}^{-1}$ de prohexadiona de cálcio reduziram a produção por planta e o rendimento total de frutos, enquanto a aplicação de $50 \mathrm{mg} \mathrm{L}^{-1}$ não causou qualquer alteração no rendimento quando comparado ao controle. A concentração mais baixa de prohexadiona de cálcio pode ser usada para controlar o alongamento excessivo de mudas de berinjela sem perda de rendimento.
\end{abstract}

Termos para indexação: Solanum melongena, inibidor de crescimento, controle de altura de mudas.

\section{Introduction}

Eggplant (Solanum melongena L.) is initially grown in tunnels or greenhouses and then transplanted as seedlings to the field. These transplants are commonly grown in plug trays at high plant densities due to production costs. However, high plant density results in morphological changes collectively referred to as shade-avoidance response. Plants that shade each other develop longer stems and produce less dry matter to compete for the limited amount of light in the plant canopy. The resulting tall, weak-stemmed seedlings 
are difficult to transplant and are easily damaged (Garner \& Björkman, 1996). Tall seedlings are also less compatible with transplanting machines than more moderately-sized plants, since mechanical transplanters are designed to accommodate plants of a specific size (Bozokalfa, 2008). Besides that, unfavorable weather conditions can delay field preparation for transplanting. In this case, seedlings should be kept in a hotbed or greenhouse. This causes the seedlings to grow taller unless adequate measures are taken to control plant height. For these reasons, controlling seedling height is vital for vegetable transplant production in both greenhouse and field conditions.

Several chemical growth promoters or retardants have been used to treat plants in order to control the growth and development of vegetative or reproductive parts. Sumagic (uniconazole) is the only growth regulator labeled as a foliar spray for use on eggplant seedlings. A single Sumagic spray application between 5.0 and $10 \mathrm{mg} \mathrm{L}^{-1}$ on eggplants is suggested as a starting rate. Runkle \& Blanchard (2012) reported that there was little or no effect of Sumagic on eggplant height at the rates of $1.25,2.5$, and $5.0 \mathrm{mg} \mathrm{L}^{-1}$, although plants treated with Sumagic had smaller leaves. Therefore, rates greater than $5.0 \mathrm{mg} \mathrm{L}^{-1}$ are likely required to suppress stem elongation (Runkle \& Blanchard, 2012). Plant growth regulators (PGRs) that inhibit gibberellin biosynthesis have been effectively used to control transplant height. One of the PGRs used to control plant height in recent years is prohexadione calcium, which inhibits the production of growth-active gibberellins, retarding shoot elongation.

Prohexadione calcium has shown excellent vegetative growth-control properties in a number of plant species, such as rice, apple, petunia, and various vegetable crops, including cucumber and tomato (Ilias \& Rajapakse, 2005; Ergun et al., 2007; Kim et al., 2007; Altintas, 2011). Soaking of faba bean seeds in solutions of prohexadione calcium caused significant reduction in shoot height and shoot fresh weight, with increasing prohexadione calcium concentrations (Bekheta et al., 2009). Currently, prohexadione calcium has been classified as a reduced-risk compound, since it exhibits negligible toxicological effects on mammals and has been reported to degrade in higher plants with a half-life of a few weeks and in soil with a half-life of less than a week. Therefore, prohexadione calcium is not persistent in the environment and has a low potential for bioaccumulation (Ilias \& Rajapakse, 2005).
However, there are no known works on the response of the growth retardant prohexadione calcium in controlling the growth and development of the vegetative or reproductive parts of vegetable crop species, like eggplant.

The objective of this work was to evaluate the effects of prohexadione calcium concentrations on the growth and quality of eggplant (Solanum melongena) seedlings.

\section{Materials and Methods}

Greenhouse and field experiments were conducted from April 2009 to October 2011 at the Horticultural Sciences Research Unit of Kahramanmaras Sutcu Imam University, in Kahramanmaras, Turkey $\left(37^{\circ} 35^{\prime} \mathrm{N}\right.$, $36^{\circ} 49^{\prime} \mathrm{E}$, at $502 \mathrm{~m}$ altitude).

'Faselis F1' eggplant seeds from De Ruiter Seeds (Bergschenhoek, Holland), which are commonly grown in Turkey, were used in the study.

The effects of prohexadione calcium concentrations on seedling growth parameters were evaluated in greenhouse conditions. The greenhouse experiment was carried out in a completely randomized design with four replicates. Seedlings were grown in an unheated greenhouse with average day/night temperature of $30.5 / 20.3^{\circ} \mathrm{C}$ and relative humidity of $55 \%$. Untreated eggplant seeds were sown in 35 -cell plastic trays $\left(100 \mathrm{~cm}^{3}\right.$ cell volume), which were filled with a media consisting of peat and perlite in the ratio of $4: 1$ and placed on a greenhouse bench. Seedlings were watered daily and fertilized with 20-20-20 N-P-K soluble fertilizer at a rate of $200 \mathrm{mg} \mathrm{L}^{-1} \mathrm{~N}$ (20 mL per plant) once a week. At the emergence of the third true leaf (20 days after sowing), eggplant seedlings were sprayed one time with $0,50,100$, or $150 \mathrm{mg} \mathrm{L}^{-1}$ prohexadione calcium solutions containing $0.1 \%$ Tween 20 (Sigma-Aldrich, St. Louis, MO, USA) as a wetting agent. A solution containing $0.1 \%$ Tween 20 was applied to the control plants. The eggplant seedlings were sprayed to run-off. At the time of spraying, the surface of the growing medium was covered with aluminum foil to minimize the contact of the growth regulator solutions with the substrate. At 35 days after sowing, the greenhouse experiment was discontinued and final seedling growth measurements were taken. Ten plants per treatment were randomly chosen from each 
replicate to determine seedling height, internode length, stem diameter, number of true leaves, relative leaf chlorophyll content with a chlorophyll meter SPAD-502 (Konica Minolta Sensing, Inc., Sakai, Osaka, Japan), leaf area with a leaf area meter LI-3100C (LI-COR Biosciences, Lincoln, Nebraska, USA), shoot fresh and dry weights, and root fresh and dry weights, after samples were dried in the oven at $80^{\circ} \mathrm{C}$ until constant weight.

The seedlings from the greenhouse experiment were transplanted to the field in order to investigate the effects of prohexadione calcium on growth and yield parameters. The experimental plots consisted of two rows of 10 plants each, with 20 plants per treatment, with a drip irrigation tube in the middle. The beds were $120 \mathrm{~cm}$ apart, with plant rows spaced at $50 \mathrm{~cm}$ and plants within each row also at $50 \mathrm{~cm}(120 \times 50 \times 50 \mathrm{~cm})$. During the field experiment, the effects of prohexadione calcium were observed on number of days to flowering, plant heights measured at 35 and 70 days after the treatments (DAT), number of fruits per plant, average fruit weight, and fruit yield.

The field experiment was also carried out in a completely randomized design with four replicates. Both the greenhouse and the field experiments were repeated twice and resulted in similar data. After conducting Levene's test to confirm the possibility of grouping, the data from the two experiments were combined and subjected to analysis of variance using the SAS software, version 9.1. (SAS Institute Inc., Cary, NC, USA), and mean separation was performed by Fisher's least significant difference (LSD) test when the $\mathrm{F}$ test was significant at 5\% probability.

\section{Results and Discussion}

The application of prohexadione calcium reduced vegetative growth, most clearly shown by a reduction in plant height and internode length, in comparison to the control treatment (Table 1). With the concentrations of 50,100, and $150 \mathrm{mg} \mathrm{L}^{-1}$ prohexadione calcium, shoot height was suppressed by 27,32 , and $38 \%$, respectively, when compared to the control. All prohexadione calcium concentrations significantly reduced internode length in comparison to the control. These results are in agreement with previous studies conducted with other vegetable and fruit crops (Rayirath et al., 2009; Kim et al., 2010; Guak, 2013). Soaking of faba bean (Vicia faba L.) seeds in solutions of prohexadione calcium caused significant reduction in shoot height and fresh weight, with increasing prohexadione calcium concentrations (Bekheta et al., 2009). Similarly, Ouzounidou et al. (2011) reported significant inhibition of shoot height in onion (Allium cepa L.) and garlic (Allium sativum L.) with the application of prohexadione calcium. The inhibitory effect of prohexadione calcium on seedling height is further supported by other researches on cabbage (Brassica oleracea var. capitata) by Hamano et al. (2002), petunia (Petunia x hybrida Vilm.-Andr.) and impatiens (Impatiens walleriana Hook.f.) by Ilias \& Rajapakse (2005), tomato (Lycopersicum esculentum Mill.) by Giannakoula \& Ilias (2007), and okra [Abelmoschus esculentus (L.) Moench] by Ilias et al. (2007).

Therewere no significant differences in stem diameter and number of true leaves between the prohexadione calcium treatments and the control plants (Table 1). These results can be interpreted as an advantage

Table 1. Effects of prohexadione calcium treatments on shoot height, internode length, stem diameter, number of true leaves, and leaf area of 5-week-old eggplant (Solanum melongena) seedlings ${ }^{(1)}$.

\begin{tabular}{lccccc}
\hline $\begin{array}{l}\text { Prohexadione calcium } \\
\left(\mathrm{mg} \mathrm{L}^{-1}\right)\end{array}$ & $\begin{array}{c}\text { Shoot height } \\
(\mathrm{cm})\end{array}$ & $\begin{array}{c}\text { Internode length } \\
(\mathrm{cm})\end{array}$ & $\begin{array}{c}\text { Stem diameter } \\
(\mathrm{mm})\end{array}$ & $\begin{array}{c}\text { Number of true leaves } \\
(\text { leaves per plant })\end{array}$ & $\begin{array}{c}\text { Leaf area } \\
\left(\mathrm{cm}^{2} \text { per plant }\right)\end{array}$ \\
\hline 0 & $6.75 \mathrm{a}$ & $1.84 \mathrm{a}$ & 2.68 & 4.73 & $79.83 \mathrm{a}$ \\
50 & $4.95 \mathrm{~b}$ & $0.99 \mathrm{~b}$ & 2.68 & 4.57 & $75.91 \mathrm{~b}$ \\
100 & $4.63 \mathrm{~b}$ & $0.83 \mathrm{~b}$ & 2.71 & 4.60 & $72.36 \mathrm{~b}$ \\
150 & $4.08 \mathrm{~b}$ & $0.80 \mathrm{~b}$ & 2.67 & 4.63 & $68.19 \mathrm{~b}$ \\
\hline $\mathrm{LSD}_{0.05}$ & 0.93 & 0.38 & 0.31 & 0.35 & 8.20 \\
\hline Significance & $* * *$ & $* * *$ & ns & ns \\
\hline
\end{tabular}

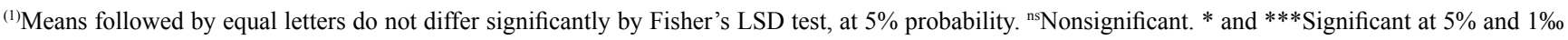
probability, respectively. 
of using prohexadione calcium because it reduced eggplant seedling height without negatively affecting stem diameter and number of true leaves. There are no known previous studies on the use of prohexadione calcium on eggplant supporting or contradicting the obtained results. In a previous study conducted on tomato seedlings, the application of prohexadione calcium decreased both stem diameter and number of true leaves (Altintas, 2011). In contrast, Kofidis et al. (2008) found that stems of coriander (Coriandrum sativum L.) plants treated with prohexadione calcium had greater diameter than those of the controls, and were more compact and stronger due to the increased volume of the collenchyma tissue and the greater number of vessels in the vascular bundles.

The highest concentration of prohexadione calcium $\left(150 \mathrm{mg} \mathrm{L}^{-1}\right)$ reduced leaf area of eggplant seedlings by $15 \%$, when compared to the control plants, but there were no significant differences among the control and the other prohexadione calcium treatments (50 and $\left.100 \mathrm{mg} \mathrm{L}^{-1}\right)$. It is important to highlight that reduced leaf area can lower photosynthesis. Davis et al. (1988) observed that the photosynthetic rate decreased as a result of leaf expansion inhibition. However, it has been reported that prohexadione calcium had a positive effect on photosynthesis on some crops, such as strawberries (Fragaria x ananassa Duchesne) (Reekie et al., 2005). The mechanistic basis for the positive effect of prohexadione calcium on photosynthesis may be related to its effect on leaf area. In the present study, in comparison to the control, treated leaves had lower leaf area and higher chlorophyll content on a leaf area basis (Table 2).

These findings agree with previous studies on the application of prohexadione calcium and of some regulators of the triazole group on apples (Malus slyvestris var. domesticus) (Glenn \& Miller, 2005; Medjdoub et al., 2007). It has been reported that the application of prohexadione calcium decreased leaf area of tomato plants when compared to the control (Altintas, 2011). Reduced leaf area with increasing concentrations is most likely due to the inhibition of gibberellin biosynthesis (Rademacher, 2000). Kang et al. (2010) found that the endogenous bioactive $\mathrm{GA}_{1}$ and $\mathrm{GA}_{4}$ contents of Chinese cabbage (Brassica rapa L.) drastically decreased with elevated prohexadione calcium.

The highest concentration of prohexadione calcium $\left(150 \mathrm{mg} \mathrm{L}^{-1}\right)$ resulted in a reduction of 14 and $15 \%$, respectively, in shoot fresh and dry weights of eggplant seedlings (Table 2). These results are in alignment with Grossmann et al. (1994), who observed that the treatment of wheat (Triticum aestivum L.) seedlings with increasing prohexadione calcium concentrations in hydroponics reduced shoot fresh weight up to $40 \%$. In the present study, the concentration of $150 \mathrm{mg} \mathrm{L}^{-1}$ prohexadione calcium resulted in some reduction in root fresh weight of eggplant seedlings; however, no significant differences in root dry weight among prohexadione calcium treatments were found (Table 2).

Prohexadione calcium treatments (except the one with $50 \mathrm{mg} \mathrm{L}^{-1}$ ) enhanced relative leaf chlorophyll content, in comparison to the control (Table 2). Sabatini et al. (2003) found that prohexadione calcium positively affected the leaf chlorophyll content of apple and pear (Pyrus communis L.) trees. These authors observed that prohexadione calcium increased net photosynthesis and concluded it had a positive influence on fruit weight and yield. Kofidis et al. (2008) reported no significant differences in chlorophyll content

Table 2. Effects of prohexadione calcium treatments on shoot fresh weight, shoot dry weight, root fresh weight, root dry weight, and relative leaf chlorophyll content (SPAD units) of 5-week-old eggplant (Solanum melongena) seedlings ${ }^{(1)}$.

\begin{tabular}{lccccc}
\hline $\begin{array}{l}\text { Prohexadione calcium } \\
\left(\mathrm{mg} \mathrm{L}^{-1}\right)\end{array}$ & $\begin{array}{c}\text { Shoot fresh weight } \\
(\mathrm{g})\end{array}$ & $\begin{array}{c}\text { Shoot dry weight } \\
(\mathrm{mg})\end{array}$ & $\begin{array}{c}\text { Root fresh weight } \\
(\mathrm{g})\end{array}$ & $\begin{array}{c}\text { Root dry weight } \\
(\mathrm{mg})\end{array}$ & $\begin{array}{c}\text { SPAD } \\
0\end{array}$ \\
\hline 0 & $2.23 \mathrm{a}$ & $233 \mathrm{a}$ & $1.18 \mathrm{a}$ & 65.33 & $33.74 \mathrm{~b}$ \\
50 & $2.09 \mathrm{ab}$ & $230 \mathrm{ab}$ & $1.10 \mathrm{ab}$ & 64.00 & $36.23 \mathrm{ab}$ \\
100 & $1.97 \mathrm{~b}$ & $223 \mathrm{ab}$ & $1.07 \mathrm{ab}$ & 61.67 & $37.63 \mathrm{a}$ \\
150 & $1.91 \mathrm{~b}$ & $197 \mathrm{~b}$ & $1.03 \mathrm{~b}$ & 60.00 & $38.00 \mathrm{a}$ \\
\hline LSD $_{0.05}$ & 0.18 & 15.75 & 0.14 & 15.80 & 2.69 \\
\hline Significance & $* *$ & $* *$ & $*$ & ns \\
\hline
\end{tabular}

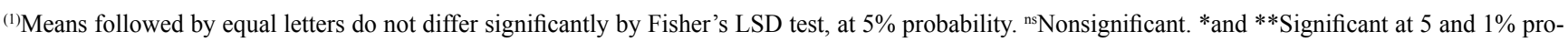
bability, respectively. 
between leaves treated with prohexadione calcium and control leaves of coriander plants. In contrast, Meagy (2009) stated that high concentrations of prohexadione calcium significantly reduced chlorophyll in spearmint (Mentha spicata L.) plants when compared to the control. Similarly, prohexadione calcium treatments (100-300 $\left.\mathrm{mg} \mathrm{L}^{-1}\right)$ resulted in a significant decline in the leaf chlorophyll content of tomato plants (Giannakoula \& Ilias, 2007).

Significant reductions in plant height were observed with higher prohexadione calcium concentrations (100 and $\left.150 \mathrm{mg} \mathrm{L}^{-1}\right)$ in the field experiment at 35 DAT (Figure 1). Prohexadione calcium treatments resulted in a reduction of $11 \%$ in plant height at 35 DAT, but in no significant reduction at 70 DAT. These results show that prohexadione calcium lost its growth inhibitory effectiveness over time, indicating prohexadione

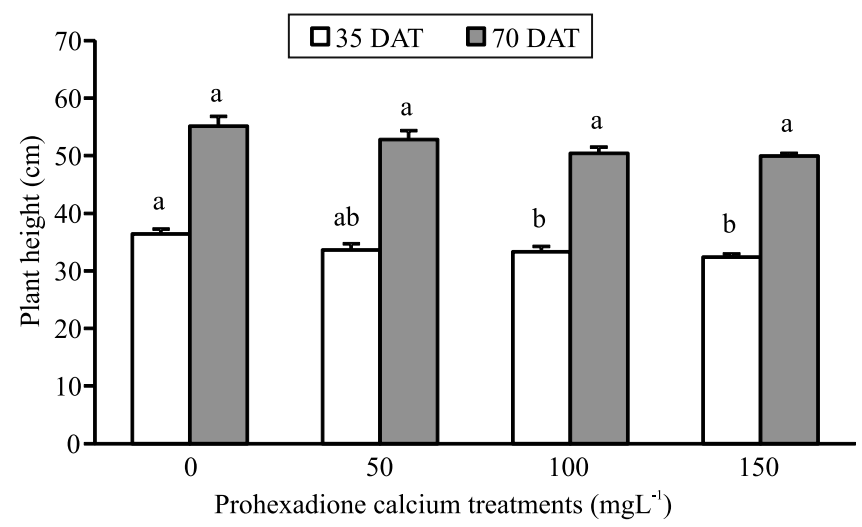

Figure 1. Effect of prohexadione calcium treatments on the height of eggplant (Solanum melongena) plants measured 35 and 70 days after the treatment (DAT). Bars with equal letters do not differ significantly by Fisher's LSD test, at 5\% probability. calcium has low toxicity and persistence in the plant (Ilias \& Rajapakse, 2005). This is important to control plant height in vegetable crops, such as eggplants. According to Greene \& Schloemann (2010), inhibitory effects of an application of prohexadione calcium lasted for about 28 days.

No delays in flowering were observed in eggplant plants due to prohexadione calcium treatments (Table 3). This is an advantage of using prohexadione calcium instead of some other growth retardant, including abscisic acid and chlorocholine chloride. Growth retardants may delay flowering in vegetable crops, including eggplants, and cause yield and income losses. These findings on eggplant flowering are in line with Ilias et al. (2007), who reported that control and prohexadione-calcium-treated okra plants took the same time to bloom. In contrast, the application of $200 \mathrm{mg} \mathrm{L}^{-1}$ prohexadione calcium, 45 days after planting, delayed anthesis up to 11 days (Cerny-Koenig et al., 2005). This may be explained by the late application of the retardant. In the present study, no significant differences in number of fruits per plant among prohexadione calcium treatments were found (Table 3). These results confirm those obtained by Mandemaker et al. (2005), who observed no differences in fruit number or size between untreated and treated avocado (Persea americana Mill.) plants with prohexadione calcium.

The highest concentration of prohexadione calcium (150 $\left.\mathrm{mg} \mathrm{L}^{-1}\right)$ reduced mean fruit weight by $7 \%$ in comparison to the control plants (Table 3 ), and there were no significant differences among the control and the other prohexadione calcium treatments (50 and $100 \mathrm{mg} \mathrm{L}^{-1}$ ). These findings are consistent with those of Sugar et al. (2004), who reported that mean fruit weight in pear was reduced by prohexadione

Table 3. Effects of prohexadione calcium treatments on days to flowering, number of fruits, mean fruit weight, yield per plant, early and total marketable yield of eggplant (Solanum melongena $)^{(1)}$.

\begin{tabular}{|c|c|c|c|c|c|c|}
\hline $\begin{array}{l}\text { Prohexadione calcium } \\
\left(\mathrm{mg} \mathrm{L}^{-1}\right)\end{array}$ & $\begin{array}{c}\text { Days to flowering } \\
\text { (days) }\end{array}$ & $\begin{array}{l}\text { Number of fruits } \\
\text { (fruits per plant) }\end{array}$ & $\begin{array}{l}\text { Mean fruit weight } \\
(\mathrm{g})\end{array}$ & $\begin{array}{l}\text { Yield per plant } \\
(\mathrm{kg})\end{array}$ & $\begin{array}{l}\text { Early marketable } \\
\text { yield }\left(\mathrm{Mg} \mathrm{ha}^{-1}\right)^{(2)}\end{array}$ & $\begin{array}{c}\text { Total marketable } \\
\text { yield }\left(\mathrm{Mg} \mathrm{ha}^{-1}\right)\end{array}$ \\
\hline$\overline{0}$ & 53 & 14.25 & $173.68 \mathrm{a}$ & $2.44 \mathrm{a}$ & $9.58 \mathrm{a}$ & $65.03 \mathrm{a}$ \\
\hline 50 & 54 & 13.83 & $168.82 \mathrm{ab}$ & $2.33 \mathrm{a}$ & $9.34 \mathrm{a}$ & $62.23 \mathrm{a}$ \\
\hline 100 & 54 & 13.08 & $165.13 \mathrm{ab}$ & $2.20 \mathrm{~b}$ & $8.28 b$ & $58.58 \mathrm{~b}$ \\
\hline 150 & 55 & 12.84 & $162.18 \mathrm{~b}$ & $2.11 \mathrm{~b}$ & $7.29 \mathrm{c}$ & $56.24 \mathrm{~b}$ \\
\hline $\mathrm{LSD}_{0.05}$ & 2.82 & 2.36 & 9.55 & 0.13 & 0.37 & 3.41 \\
\hline Significance & ns & ns & $*$ & $* *$ & $* * *$ & $* *$ \\
\hline
\end{tabular}

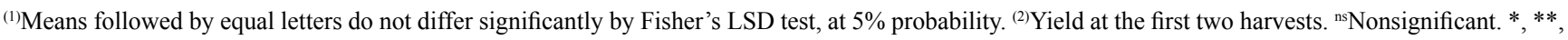
and $* * *$ Significant at $5 \%, 1 \%$, and $1 \%$ probability, respectively. 
calcium treatments. Prohexadione calcium may be reducing fruit size primarily by slowing down cell division development in fruits (Greene, 2008). An alternative or contributing factor to reducing fruit size could be reduced leaf area (Greene, 2008), which is true in the case of the present study. A reduction in leaf area, which may reduce carbohydrate supply to the developing fruit, could also reduce fruit size. The present study showed that the mean fruit weight was reduced by the application of $150 \mathrm{mg} \mathrm{L}^{-1}$, whereas fruit number per plant was not affected. Linearity was also observed between mean fruit weight and yield per plant (Table 3).

The highest prohexadione calcium concentrations (100 and $150 \mathrm{mg} \mathrm{L}^{-1}$ ) significantly reduced yield per plant, as well as early and total marketable yield of eggplant, whereas $50 \mathrm{mg} \mathrm{L}^{-1}$ did not cause any change in yield when compared to the control (Table 3). These results are similar to those reported for coriander plants by Kofidis et al. (2008). These authors found that 100 and $200 \mathrm{mg} \mathrm{L}^{-1}$ prohexadione calcium led to significant decreases in fruit yield when in comparison to the control. However, the results obtained in the present study are contrary to those of other works. Greene \& Schloemann (2010) observed that prohexadione calcium increased total marketable yield without affecting mean fruit size. Asín et al. (2007) concluded that prohexadione calcium did not have any significant negative effect on pear yield. Therefore, the improving or negative effect of prohexadione calcium depends on application time, doses, environmental conditions, species, cultivar, and even on the individual plant (Altintas, 2011).

\section{Conclusions}

1. Prohexadione calcium is effective in reducing shoot height in eggplant (Solanum melongena), and the response varies with the applied concentration.

2. The lowest prohexadione calcium concentration (50 $\mathrm{mg} \mathrm{L}^{-1}$ ) can be used to control excessive elongation of eggplant seedlings without any major yield loss.

\section{References}

ALTINTAS, S. Effects of prohexadione-calcium with three rates of phosphorus and chlormequat chloride on vegetative and generative growth of tomato. African Journal of Biotechnology, v.75, p.17142-17151, 2011. DOI: 10.5897/AJB11.2594.
ASÍN, L.; ALEGRE, S.; MONTSERRAT, R. Effects of paclobutrazol, prohexadione-Ca, deficit irrigation, summer pruning and root pruning on shoot growth, yield and return bloom, in a 'Blanquilla' pear orchard. Scientia Horticulturae, v.113, p.142-148, 2007. DOI: 10.1016/j.scienta.2007.02.008.

BEKHETA, M.A.; ABDELHAMID, M.T.; EL-MORSI, A.A. Physiological response of Vicia faba to prohexadione-calcium under saline conditions. Planta Daninha, v.27, p.769-779, 2009. DOI: $10.1590 / \mathrm{S} 0100-83582009000400015$.

BOZOKALFA, M.K. Irrigation temperature effects on seedling growth and transplant quality of tomato, pepper and eggplant. Spanish Journal of Agricultural Research, v.6, p.120-124, 2008. DOI: $10.5424 /$ sjar/2008061-5250.

CERNY-KOENIG, T.A.; FAUST, J.E.; RAJAPAKSE, N.C. Role of gibberellin $\mathrm{A}_{4}$ and gibberellin biosynthesis inhibitors on flowering and stem elongation in Petunia under modified light environments. HortScience, v.40, p.134-137, 2005.

DAVIS, T.D.; STEFFENS, G.L.; SANKHLA, N. Triazole plant growth regulators. Horticultural Reviews, v.10, p.63-105, 1988. DOI: $10.1002 / 9781118060834 . c h 3$.

ERGUN, N.; CAGLAR, G.; OZBAY, N.; ERGUN, M. Hiyar fide kalitesi ve bitki gelişimi üzerine prohexadione-calcium uygulamalarının etkileri. Bahçe, v.36, p.49-59, 2007.

GARNER, L.C.; BJÖRKMAN, T. Mechanical conditioning for controlling excessive elongation in tomato transplants: sensitivity to dose, frequency, and timing of brushing. Journal of the American Society for Horticultural Science, v.121, p.894-900, 1996.

GIANNAKOULA, A.; ILIAS, I. Chlorophyll fluorescence and photosystem II activity of tomato leaves as affected by irradiance and prohexadione-calcium. In: WSEAS INTERNATIONAL CONFERENCE ON RENEWABLE ENERGY SOURCES, 2007, Arcachon. Proceedings. Arcachon: World Scientific and Engineering Academy and Society, 2007. p.49-56.

GLENN, D.M.; MILLER, S.S. Effects of Apogee on growth and whole-canopy photosynthesis in spur 'Delicious' apple trees. HortScience, v.40, p.397-400, 2005.

GREENE, D.W. The effect of repeat annual applications of prohexadione-calcium on fruit set, return bloom, and fruit size of apples. HortScience, v.43, p.376-379, 2008.

GREENE, D.W.; SCHLOEMANN, S.G. Prohexadione-calcium inhibits runner formation and enhances yield of strawberry. Journal of the American Pomological Society, v.64, p.125-139, 2010.

GROSSMANN, K.; KONIG-KRANZ, S.; KWIATKOWSKI, J. Phytohormonal changes in intact shoots of wheat and oilseed rape treated with the acylcyclohexanedione growth retardant prohexadione calcium. Physiologia Plantarum, v.90, p.139-143, 1994. DOI: 10.1111/j.1399-3054.1994.tb02203.x.

GUAK, S. Effects of prohexadione-Ca, ethephon, and water stress on growth and productivity of 'Golden Delicious'/M.9 apple. Korean Journal of Horticultural Science and Technology, v.31, p.38-49, 2013. DOI: 10.7235/hort.2013.12191.

HAMANO, M.; YAMATO, Y.; AMAZAKI, H.; MIURA, H. Endogenous gibberellins and their effects on flowering and stem 
elongation in cabbage (Brassica oleracea var. capitata). Journal of Horticultural Science \& Biotechnology, v.77, p.220-225, 2002.

ILIAS, I.; OUZOUNIDOU, G.; GIANNAKOULA, A.; PAPADOPOULOU, P. Effects of gibberellic acid and prohexadione-calcium on growth, chlorophyll fluorescence and quality of okra plant. Biologia Plantarum, v.51, p.575-578, 2007. DOI: $10.1007 / \mathrm{s} 10535-007-0126-5$.

ILIAS, I.F.; RAJAPAKSE, N. Prohexadione-calcium affects growth and flowering of petunia and impatiens grown under photoselective films. Scientia Horticulturae, v.106, p.190-202, 2005. DOI: 10.1016/j.scienta.2005.02.023.

KANG, S.-M.; KIM, J.-T.; HAMAYUN, M.; HWANG, I.-C.; KHAN, A.L.; KIM, Y.-H.; LEE, J.-H.; LEE, I.-J. Influence of prohexadione-calcium on growth and gibberellins content of Chinese cabbage grown in alpine region of South Korea. Scientia Horticulturae, v.125, p.88-92, 2010. DOI: 10.1016/j. scienta.2010.02.018.

KIM, H.Y.; LEE, I.J.; HAMAYUN, M.; KIM, J.T.; WON, J.G.; HWANG, I.C.; KIM, K.U. Effect of prohexadione calcium on growth components and endogenous gibberellins contents of rice (Oryza sativa L.). Journal of Agronomy and Crop Science, v.193, p.445-451, 2007. DOI: 10.1111/j.1439-037X.2007.00280.x.

KIM, Y.H.; KHAN, A.L.; HAMAYUN, M.; KIM, J.T.; LEE, J.H.; HWANG, I.C.; YOON, C.S.; LEE, I.J. Effects of prohexadione calcium on growth and gibberellins contents of Chrysanthemum morifolium R. cv. Monalisa White. Scientia Horticulturae, v.123, p.423-427, 2010. DOI: 10.1016/j.scienta.2009.09.022.

KOFIDIS, G.; GIANNAKOULA, A.; ILIAS, I.F. Growth, anatomy and chlorophyll fluorescence of coriander plants (Coriandrum sativum L.) treated with prohexadione-calcium and daminozide. Acta Biologica Cracoviensia, v.50, p.55-62. 2008.

MANDEMAKER, A.J.; CUTTING, J.G.M.; SMITH, D.B.; DIXON, J. Effect of prohexadione-Ca on shoot growth, fruit set and retention in 'Hass' avocado in New Zealand. New Zealand Avocado Grower's Association Annual Research Report, v.5, p.35-42, 2005.
MEAGY, M.D.J. Effect of prohexadione-calcium on spearmint (Mentha spicata L.). 2009. 55p. Thesis (Master of Science) University of Massachusetts, Amherst.

MEDJDOUB, R.; VAL, J.; BLANCO, A. Physiological effects of prohexadione-calcium in apple trees: effects on parameters related to photoproductivity. Journal of Horticultural Science and Biotechnology, v.82, p.126-132, 2007.

OUZOUNIDOU, G.; GIANNAKOULA, A.; ASFI, M.; ILIAS, I. Differential responses of onion and garlic against plant growth regulators. Pakistan Journal of Botany, v.43, p.2051-2057, 2011.

RADEMACHER, W. Growth retardants: effects on gibberellin biosynthesis and other metabolic pathways. Annual Review of Plant Physiology and Plant Molecular Biology, v.51, p.501-531, 2000. DOI: 10.1146/annurev.arplant.51.1.501.

RAYIRATH, U.P.; LADA, R.R.; CALDWELL, C.D.; ASIEDU, S.K.; SIBLEY, K.J.; ADAMS, A.D. CCC and prohexadione-Ca enhance rhizome growth and lateral bud production in rhubarb (Rheum rhabarbarum L.). Journal of Plant Growth Regulation, v.28, p.137-146, 2009. DOI: 10.1007/s00344-009-9082-y.

REEKIE, J.Y.; HICKLENTON, P.R.; STRUIK, P.C. Prohexadione-calcium modifies growth and increases photosynthesis in strawberry nursery plants. Canadian Journal of Plant Science, v.85, p.671-677, 2005. DOI: 10.4141/P04-113.

RUNKLE, E.; BLANCHARD, M. Sumagic on vegetable transplants. Greenhouse Product News, v.22, p.58, Nov. 2012. Available at: <http://flor.hrt.msu.edu/assets/Uploads/ Sumagiconvegetables.pdf $>$. Accessed on: 9 Aug. 2015.

SABATINI, E.; NOFERINI, M.; FIORI, G.; GRAPPADELLI,L.C.; COSTA, G. Prohexadione-Ca positively affects gas exchanges and chlorophyll content of apple and pear trees. European Journal of Horticultural Science, v.68, p. 123-128, 2003.

SUGAR, D.; ELFVING, D.C.; MIELKE, E.A. Effects of prohexadione-calcium on fruit size and return bloom in pear. HortScience, v.39, p.1305-1308, 2004. 